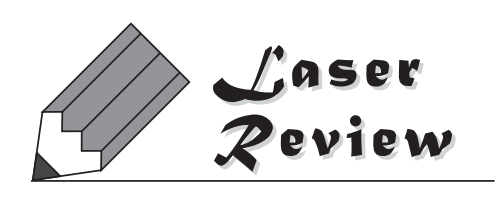

\title{
「パルス電子線による光励起ダイナミクス研究の最前線」 解説小特集によせて
}

\author{
板倉 隆二 \\ 日本原子力研究開発機構 量子ビーム応用研究センター（７６19-0215 京都府木津川市梅美台8-1-7）

\section{Preface to Topical Papers on Frontier of Pulsed Electron Beam for Research on Photoexcited Dynamics} \\ Ryuji ITAKURA \\ Quantum Beam Science Center, Japan Atomic Energy Agency, 8-1-7 Umemidai, Kizugawa, Kyoto 619-0215
}

(Received December 5, 2014)

近年, 高強度のパルスX線や中性子がX線自由電子 レーザー(XFEL，SACLA)や大強度陽子加速施設 (J-PARC) などの加速器ベースの大型施設によって実現 され，たんぱく質などの構造解析について大きな進展が 期待されている.X線や中性子と同様に構造解析におけ る有力なビームである電子線についても, 超短パルス レーザーと融合した短パルス化の進展には目を見張るも のがあり, 装置開発の段階から利用研究の段階へと移行 しつつある. 特に, 大型加速器が不要であることから実 験室レベルのコンパクトな装置にできるため, コストや 実験時間の確保などの運用上の面で大きな利点がある。 X線，中性子，そして電子線散乱の物理的な違いについ ては, 後の解説論文をご参照頂きたい. 従来の電子顕微 鏡の歴史についてもご紹介頂いているのでご一読頂きた い.

パルス電子線装置は, SACLAやJ-PARCのように大々 的に宣伝されることがないため, 専門家以外に知られる 機会に乏しいが，もっと多くの方に認知されて然るべき 計測装置である，ピコ〜フェムト秒のパルス幅をもつパ ルス電子線を発生させるには, 超短パルスレーザーの存 在なしには実現できず，利用研究においても超短パルス レーザーを励起源として使う。超短紫外レーザーパルス を金属表面に照射し, 光電効果によって超短電子パルス を発生させる方法を提案し, 時間分解電子線回折を最初 に実現したのが1)，超短パルスレーザーの増幅に不可欠 となっているチャープパルス増幅法 (CPA)を提案したG. Mourou教授であることからも, 超短パルスレーザーと パルス電子線が密接な関係にあることがわかる。ここ数 年の間に, 日本国内でも世界をリードするパルス電子線 の利用研究がいくつか出てきており, 本誌にて特集を組 むのに時機を得ていると考え，企画を立案した。

電子線を構造解析に利用するには, いくつかの方法が
あるが，まずは，回折法による利用が挙げられる，複数 の原子で弾性散乱されたそれぞれの球面電子散乱波の干 渉が回折像として現れ, 干渉パターンから構造を決める ことができる。電子線回折は，規則正しく原子が配置さ れた固体結晶だけでなく，向きがランダムな気体分子集 団にも適用でき, 分子内の原子間距離を決めることがで きる2).

標準的な電子線発生法では, 光陰極に超短紫外レー ザーパルスを入射し, 光電効果によって超短電子パルス を発生させる。 その後の加速や電子線の伝送においてパ ルス電子線の時間分解能を悪くする大きな要因は, (1) パルス電子内の電子同士のクーロン反発と (2) エネル ギー(速度)広がりの2つが挙げられる。（1）のクーロン反 発は電子密度が上がるほど影響が大きくなるため, 電子 数を減らす方法 ${ }^{3)}$ ヤレーザー増幅のCPAと同様にエネル ギー広がりを逆に利用し, 電子パルスを広げ電荷密度を 下げて, 電子バンチを輸送し, 再度, 磁石をうまく使っ て, 試料点で最短パルスが実現するように速度毎の伝播 距離を調整する方法 ${ }^{4}$ などが提案されている.

高強度レーザーによる加速については，本誌でも2012 年11月号に特集が組まれてきており，興味のある方はご 参照頂きたい，今回の小特集では，京大化研の阪部先生 のグループによる解説論文において，レーザー加速に よって得られた高エネルギー電子パルスを実際に電子線 回折に適用した例をご紹介頂いた。レーザー加速が利用 段階に入ったという点で, 極めて重要な進展である.

加速器で使われるRF加速を利用しているのが阪大産

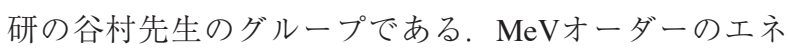
ルギーを持つ超短電子パルスを安定に発生させることに 成功している。多くの場合に使われる数10１00 keVの 電子に比べ，はるかに大きなエネルギーである $\mathrm{MeV}$ 級 の相対論的電子パルスを使う利点についてご解説頂い 
た，実測例として，金単結晶のレーザー誘起固液相転移 に関する時間分解測定の結果をご紹介頂いている.

静電場加速を用いた装置については, 東工大応セラ研 (JSTさきがけ)の羽田先生にご解説頂いた。時間分解能 を上げるために加速領域を短くした結果, 装置が小型化 され，まさにテーブルトップの電子線回折装置が実現さ れている。この装置を利用した実験例として, 超短パル スレーザー照射されたアルカリハライド結晶の融解・ア ブレーション現象の時間分解回折像が示された。電子線 回折だけでなく，時間分解反射率測定やアブレーション によって生成したイオンの測定といった別の計測手法も 駆使することによって多面的な議論がなされ，全体像が 浮かび上がってくることがわかる.

これまで電子線回折による原子構造配置の観測につい て述べてきたが, 非弾性散乱, すなわち入射電子の工ネ ルギー損失に着目し, 物質中の電子構造を明らかにしよ うとする試みも, 東北大多元研の高橋先生, 山崎先生の グループで行われてきた。 高速電子を入射し, 非弾性散 乱された電子と電離された価電子の 2 つ電子の運動量 を同時に観測し, 電離前の価電子の運動量分布を求める 電子コンプトン散乱実験である。超短パルス電子線を用 いれば，フェムト秒レーザーによって励起された電子状 態の時間変化を運動量空間で見ることが可能となる。実 験は極めて困難なものであるが，化学反応の遷移状態を 電子状態という根源から明らかにできる夢の実験につい てご紹介頂いた。

これまで述べてきた手法では，時間分解能はあくまで 電子線パルスに依存するが，観測する電子散乱の時間幅 をレーザーパルスで制御しようという大胆な試みも東大 院理の山内先生, 帰家先生のグループにて行われてき た。電子と分子との散乱にさらに高強度レーザーを照射 することによって, 電子, 分子, 光子の3体衝突が起こ る。レーザーパルスを光ゲートとみなすことができ, 観 測される散乱の時間幅はレーザーパルスの幅で決まる。 理論の詳細は解説論文をご参照頂くとして, すでに, こ の3体衝突から電子線回折像を抽出することに成功して おり，レーザーアシステッド電子回折と呼ばれる新しい 手法の有効性が実証されている．注意して頂きたいの は, この実験の入射電子は観測対象の分子とは独立に別 途用意されている点である。レーザー電場によって原 子・分子から放出された光電子が再び戻ってきて散乱す る自己散乱とは別の現象である.

今回の小特集では取り上げていないが，レーザー電場 1サイクルの中で起こるトンネルイオン化による自由電 子生成, レーザー電場による再加速, そしてイオンとの 再衝突という3段階モデル ${ }^{5}$ によって説明される電子の
自己散乱を利用した電子線回折 ${ }^{6)}$ や再結合による高次高 調波発生を利用した分子軌道のトモグラフィー 提案・実証され，注目を集めている.

超短パルス電子線とは少し趣が異なるが，走査型電子 顕微鏡の分解能と光学顕微鏡の操作性を融合させた新し い顕微鏡が登場していることも紹介したい。本小特集で は, 装置の要である電子線を光へ変換する蛍光薄膜に関 するオリジナル論文を掲載しているのでご一読頂きた い.

本小特集に掲載された解説論文の多くで述べられてい るように, 短パルス電子線を使った構造解析は, 現状で は，原子集団を見る回折が主流となっているが，さらな る高みを目指した研究が進められていることを強調した い. 回折はあくまで, 集団の周期構造(気体の場合は多 数分子の同じ核間距離)の観測であるため, 局所構造も しくは1分子の観測は難しい. 結晶構造の中の本当に1個 の原子, もしくは, 数個の局所的な構造や1分子を見よ うと思ったら，電子顕微鏡による実空間観測が必要とな る。「フェムト秒分光を用いた化学反応の遷移状態研究」 に対してノーベル化学賞を受賞したカルフォルニア工科 大のZewail教授は，電子顕微鏡の持つ空間的な3次元高 分解能像に加え, 新たなに時間軸を加えた4次元電子顕 微鏡というコンセプトを提唱しており ${ }^{8)}$, 国内外で時間 分解電子顕微鏡の開発が精力的に進められている.

パルス電子線を利用した光励起ダイナミクスの研究 は，時間分解能，輝度など多くが発展途上にあり，伸び 代が大きく，今後の進展が楽しみな分野である。顕微鏡 による原子の実空間測定や電子コンプトン散乱による電 子軌道分布測定, さらには, レーザーアシステッド電子 散乱による電子および分子構造の同時測定など，フェム 卜秒ナノスケールの実時間実空間で原子もしくは電子の ムービーを作るという夢は，現実に近づいてきている．

最後に，本小特集の企画にご賛同頂き，ご寄稿頂いた 先生方に深く感謝致します.

\section{参考文献}

1) G. Mourou and S. Williamson: Appl. Phys. Lett. 41 (1982) 44.

2）山内 薰：分子構造の決定（岩波書店, 2001）p. 205.

3) P. Baum: J. Phys. B 47 (2014) 124005.

4) 中新信彦, 益田伸一, 細貝知直 : レーザー研究 40 (2012) 819.

5) P. B. Corkum: Phys. Rev. Lett. 71 (1993) 1994.

6) M. Meckel, D. Comtois, D. Zeidler, A. Staudte, D. Pavicic, H. C. Bandulet, H. Pepin, J. C. Kieffer, R. Dorner, D. M. Villeneuve, et al.: Science 320 (2008) 1478.

7）板谷治郎：レーザー研究 39 (2011) 910.

8) A. H. Zewail: Science 328 (2010) 187. 